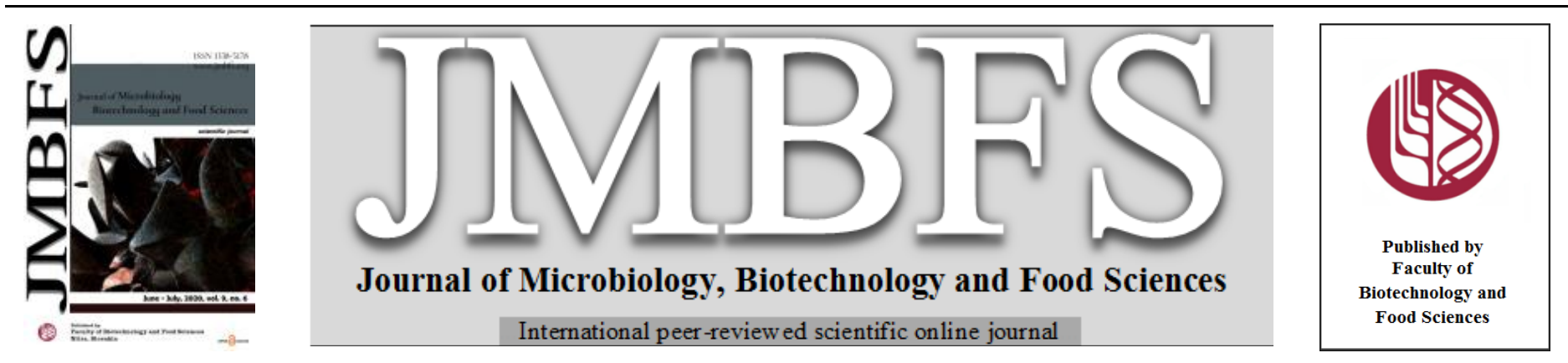

\title{
PRODUCTION OF GAMMA-AMINOBUTYRIC ACID (GABA) IN WHEY PROTEIN DRINK DURING FERMENTATION BY LACTOBACILLUS PLANTARUM
}

\author{
Fatemeh Zarei ${ }^{l}$, Leila Nateghi ${ }^{2 *}$, Mohamad Reza Eshaghi ${ }^{3}$, Maryam Ebrahimi Taj Abadi ${ }^{4}$
}

Address(es):

${ }^{1}$ Halal Research Center Islamic Republic of Tehran, Iran.

${ }^{2}$ Department of Food Science and Technology, Faculty of Agriculture, Varamin-Pishva Branch, Islamic Azad University, Varamin, Iran.

${ }^{3}$ Department of Biology, Islamic Azad University, Tehran, Iran.

*Corresponding author: 1.nathegi@iauvaramin.ac.ir

doi: 10.15414/jmbfs.2020.9.6.1087-1092

ARTICLE INFO

Received 9. 6. 2019

Revised 13. 1. 2020

Accepted 20. 1.2020

Published 1. 6. 2020

Regular article

open $\partial_{\text {AcCESS }}$

\begin{abstract}
Over the past two decades there has been a world-wide growing interest on healthy living and healthy eating. Based on our previous research, Lactobacillus plantarum, have been extracted from traditional doogh in west region of Iran and grown in MRS broth have shown the highest production of Gamma-Aminobutyric Acid (GABA) and by optimization of growth conditions the ability of GABA production increased. The best conditions of the culture medium with the highest production of GABA were temperature $37.27{ }^{\circ} \mathrm{C}, \mathrm{pH}$ 5.19 , glutamic acid $250 \mathrm{mM}$ and time 72 hours. Therefore, Lb. plantarum was added to whey protein drink containing concentrate of banana and strawberry, and its viability, production GABA and sensory evaluation of drink was evaluated within 30 days' storage. The results showed that the highest viability $\left(8.1 \log _{10} \mathrm{cfu} / \mathrm{ml}\right)$ after 30 days of storage was observed in whey protein drink containing concentrate of strawberry and storage at $25^{\circ} \mathrm{C}$. The highest amount of GABA production (195.5 ppm) after 30 days of storage was observed in whey protein drink containing concentrate of banana and stored at $25^{\circ} \mathrm{C}$. No significant differences were found between the sensory properties of the treatments. According to the results the whey protein drink containing banana stored at $25^{\circ} \mathrm{C}$ was recognized as a superior treatment due to higher levels of GABA. In conclusion, using indigenous and traditional resistant species of probiotic bacteria and optimizing bacterial growth conditions, more GABA can be produced in food products and a positive step towards the development of functional products and the promotion of consumer health.
\end{abstract}

Keywords: GABA, whey protein drink, Lactobacillus plantarum

\section{INTRODUCTION}

Over the past two decades there has been a world-wide growing interest on healthy living and thus healthy eating. However, addition of synthetic chemicals as preservatives within food industry remains unchanged. An example of such chemicals is Gamma-Aminobutyric Acid (GABA), as a bioactive agent (Kim $\boldsymbol{e} t$ al., 2008)

GABA ( $\gamma$-aminobutyric acid) is a non-protein amino acid that is widely distributed in nature among microorganisms, plants, animals. GABA acts as the main inhibitory neurotransmitter in the mammalian central nervous system (Okada et al., 2000). GABA improves the plasma concentration, growth hormones and the protein synthesis in the brain, but inhibits small airway-derived lung adenocarcinoma. Thus, GABA has hypotensive, tranquilizing, diuretic and antidiabetic effects. GABA decrease the blood pressure in animals and human subjects. The chronic GABA ingestion ranged from 0.3 to $300 \mathrm{mg} / \mathrm{kg}$ reduced systolic blood pressure in spontaneously hypertensive rats. The administration of GABA significantly decreased the blood pressure of spontaneously hypertensive rats with a dose-dependent manner. The oral administration of GABA of $10 \mathrm{mg}$ daily for 12 weeks was effective for hypertensive patients (Park and Oh, 2006). The daily oral administration of rice germ containing $26.4 \mathrm{mg}$ GABA was effective in treating neurological disorders. Furthermore, Furthermore, consumption of GABA-enriched foods can inhibit cancer cell proliferation and improve memory and the learning abilities. Therefore, GABA has been classified as a bioactive component in foods and pharmaceuticals (Nomura et al., 1998).

Lactic acid bacteria play an essential role in fermentation processes and has been used in food industry for centuries (Leroy et al., 2006). The use of lactic acid bacteria producing GABA as starting point for fermentation could potentially increase the synthesis of naturally based GABA (Dhakal et al., 2012). Thus reducing the use of chemically synthesized GABA in food industry. It is possible to use lactobacilli as a more cost-effective route to produce GABA within the food industry (Yokoyama et al., 2002). For example, use of $L b$. brevis is now being considered as a cost-effective means of producing GABA from the waste products of alcoholic beverage industry. Almost all free glutamic acid was converted into waste (Parvez et al., 2006). Whey protein-based beverages are rich in protein providing an excellent source of food for athletes (Park and Oh, 2006). Whey protein drinks often consist of a liquidized product with isolated part of the milk that is usually obtained by adding acid, heating, or coagulating the liquid cheese, giving the final product its yellowish/greenish colour. Whey proteins is a source of $\alpha$-lactalbumin, $\beta$-lactoglobulin, bovine serum albumin, caseinomacropeptides, immunoglobulins, lactoferrin, lysozyme, which are often associated with health benefits, such as enhanced immunity, anticancer properties, ant adhesive effect against pathogenic properties, as well as antiviral, antimicrobial (iron binding properties) and antihypertensive properties (Birollo, 2000). Although whey proteins are present in relatively small amounts but it has a high protein efficiency ratio, net protein utilization and biological value. In terms of nutritive value, it is closest to the egg protein. According to the definition given by the International Federation of Dairy Products (IDF), the definition of cheese is as follows: "cheese is a fermented or non-fermentable product that is obtained after the final milk, then the wheel and the mixture are obtained, with a minimum dry matter of $24 \%$ and the isolated part is called whey cheese (Harper, 2000). Whey protein has a beneficial organic matter that is fed into the process of cheese production. Whey protein has a very high chemical oxygen demand (COD) (up to 76,000 ppm) and biological oxygen demand (BOD) (up to 40,000 $\mathrm{ppm}$ ), thus considered as a highly polluted wastewater (Goyal and Gandhi, 2008). Therefore, use of bacteria producing GABA could reduce negative environmental impact of the waste produced as well as potentially preventing loss of an important source of nutrition which could have beneficial effects in disease prevention and/or disease treatment. Research showed that $L b$. plantarum DSM19463 in functional grape beverage produced the highest GABA (59 $\mu \mathrm{M} / \mathrm{h})$ (Di Cagno et al., 2010). Similarly, the adding of buckwheat

and quinoa sourdough with $\mathrm{Lb}$. plantarum $\mathrm{C} 48$ enriched the GABA production and reached to $643 \pm 13 \mathrm{mg} / \mathrm{kg}$ (Coda et al., 2010). This study was designed to investigating the potential of GABA production by probiotic bacteria in whey 
protein drink and studying the microbiological and sensory properties of probiotic whey protein drink.

\section{MATERIAL AND METHODS}

\section{Chemicals and equipment}

Triethylamine, acetonitrile, dihydrogen phosphate, acetonitrile, methanol from Merck, Germany and phenyl isothiocyanate and Ortho-Phthalic Aldehyde (OPA) and GABA standard was purchase from Sigma Aldrich, USA, and whey protein was bought from the company "Kabir Jolgeh Industries", Iran. Sugar bought from the company Neishekar. Tehran, Iran. Lb. plantarum were taken from the Takgene Zist Company, Tehran, Iran.

Preparation of whey protein drink containing concentrate of banana and strawberry inoculated with lactic acid bacteria

Based on our previous research, $L b$. plantarum, have been extracted from traditional doogh in west region of Iran and grown in MRS broth have shown the highest concentration of Gamma-Aminobutyric Acid (GABA) production $(115.24 \mathrm{ppm})$ and by optimization of growth conditions the ability of GABA production increased to $170.492 \mathrm{ppm}$ (Zarei et al., 2018). The best conditions of the culture medium with the highest production of GABA were temperature $37.27{ }^{\circ} \mathrm{C}$, pH 5.19, glutamic acid $250 \mathrm{mM}$ and time 72 hours. To produce the drink based on whey protein, $40 \%$ strawberry or banana concentrates were mixed with $3 \%$ sugar, $36 \%$ water, and $21 \%$ whey protein. To create an optimal condition for GABA production by $L b$. plantarum, the $250 \mathrm{mM}$ glutamic acid was added to the formulation and then the $\mathrm{pH}$ was adjusted to 5.19 with sodium bicarbonate. The drinks pasteurized at the temperature of $85^{\circ} \mathrm{C}$ for $10 \mathrm{~min}$ and then $\mathrm{Lb}$. plantarum bacteria $\left(10^{8} \mathrm{cfu} / \mathrm{ml}\right)$ was added into the mixture and allowed fermentation process to initiate and propagate at $37^{\circ} \mathrm{C}$ for 72 hours. Afterwards, the mixtures were kept at $4{ }^{\circ} \mathrm{C}$ and $25^{\circ} \mathrm{C}$ and assessments of $\mathrm{pH}$, microbial count prior to the fermentation, 72 hours after fermentation, 2 hours after production, and on days 15 and 30 of the storage were carried out. The content of the produced GABA was assessed on days 15 and 30 of storage and the sensory evaluation done, 2 hours after production, 15 and 30 days of storage.

\section{Viable counts of the bacteria}

Lactic acid bacteria activity was detected by measuring the viable colonies in the whey protein drinks. The diluted samples were inoculated to MRS agar plates in triplicate and the plates were incubated at $37{ }^{\circ} \mathrm{C}$ for $72 \mathrm{~h}$. Microbial count prior of the fermentation, 72 hours after fermentation, 2 hours after production, on the $15^{\text {th }}$ and $30^{\text {th }}$ days of the storage were evaluated. Viable colonies were counted and expressed as $\log \mathrm{cfu} / \mathrm{ml}$.

\section{Measuring pH}

$\mathrm{pH}$ measurements for all samples were monitored using a $\mathrm{pH}$ meter Oakton 510 (Oakton Instruments, USA) standardized with buffers 7 and 4.

\section{GABA assay using HPLC}

The drink sample was filtered through a $0.45 \mu \mathrm{m}$ membrane filter (Pall Acrodisc ${ }^{\circledR}$ Syringe Filters, Ann Arbor, MI, USA) and analysed by HPLC. Derivation was conducted accordance to the method of Bartolomeo et al. After centrifuge $\left(25^{\circ} \mathrm{C}, 10 \mathrm{~min}\right.$, and $\left.12000 \mathrm{~g}\right)$ about $20 \mu \mathrm{l}$ of supernatant were poured into a $2 \mathrm{ml}$ vial and $20 \mu 1$ Borate buffer was added and mixed vigorously. $10 \mu \mathrm{l}$ OPA was added to the sample and then it was kept for $1 \mathrm{~min}$ at ambient temperature. After $1 \mathrm{~min}, 5 \mu \mathrm{l}$ of Acetic acid 5\% was added to the sample. After derivation, $20 \mu 1$ of each sample was injected to a capillary $\mathrm{C} 18$ Column model Rstech Hector-M $(150 \mathrm{~mm} \times 4.6 \mathrm{~mm} \times 0.5 \mu \mathrm{m})$ at $25^{\circ} \mathrm{C}$, with UV-VIS detector (Younglin Acme 9000) in $\lambda=338 \mathrm{~nm}$, Sodium dihydrogen phosphate $40 \mathrm{mM}$ as mobile phase $\mathrm{A}(\mathrm{pH}$ 7.8) and Acetonitrile / Methanol/water in volume ratio of 10:45:45 as mobile phase B were used. Stock solution $\left(1 \mathrm{mgmL}^{-1}\right)$ of GABA was prepared in water, and then successively diluted to $50 \%$ to create different concentrations. Analyse content was determined from the corresponding calibration curves. The amount of GABA was calculated by comparing the peak area with the corresponding GABA standard. GABA concentration was stated based on ppm.

\section{Sensory assessment}

The whey protein drink samples were analysed for taste and smell and overall acceptability during storage at 4 and $25^{\circ} \mathrm{C}$ using 5 hedonic methods $(5=$ like very much, $4=$ like moderately, $3=$ neither like nor dislike, $2=$ dislike moderately and $1=$ dislike very much) by 10 trained panellists from the Department of Food Science and Technology, in one session, in identical containers (Larmond, 1977).

\section{Statistics}

Statistical analyses were performed using the MINITAB 14 and expressed as mean \pm standard division of three replicates $(\mathrm{p} \leq 0.05)$.

\section{RESULTS}

Changes viable counts of probiotic bacteria in whey protein drink during fermentation and storage time

The viable counts of $L$. plantarum in the whey protein drink containing concentrate of banana or strawberry fermented for $72 \mathrm{~h}$ and then kept for 30 days are shown in Table 1 . The highest viability $(9.51 \pm 0.127 \log \mathrm{cfu} / \mathrm{ml})$ was observed in the the whey protein drink containing concentrate of banana $72 \mathrm{~h}$ after fermentation and then kept at $4{ }^{\circ} \mathrm{C}$. The viable counts were continuously decreased $72 \mathrm{~h}$ after fermentation until $30^{\text {th }}$ days of storage. The lowest viable counts $(7.015 \pm 0.247 \log \mathrm{cfu} / \mathrm{ml})$ were in the whey protein drink containing concentrate of strawberry stored for 30 days at $25^{\circ} \mathrm{C}$.

According to the results of Table 5, storage time, type of the sample and their interaction had significant effect $(\mathrm{P} \leq 0.05)$ on the viability of Lactobacillus plantarum.

Table 1 Viability $(\log \mathrm{cfu} / \mathrm{ml})$ whey protein drink containing banana or strawberry concentrate stored at $4{ }^{\circ} \mathrm{C}$ and $25{ }^{\circ} \mathrm{C}$ for 30 days.

\begin{tabular}{|c|c|c|c|c|c|}
\hline Treatment & Before fermentation & $\begin{array}{c}\text { after } 72 \mathrm{~h} \\
\text { fermentation at } 37^{\circ} \mathrm{C}\end{array}$ & $\begin{array}{l}2 \text { hours after } \\
\text { production }\end{array}$ & Days 15 & Days 30 \\
\hline $\begin{array}{l}\text { Whey protein }+ \text { concentrate banana } \\
\text { stored at } 25^{\circ} \mathrm{C}\end{array}$ & $8.23 \pm 0.113^{\mathrm{aB}}$ & $9.380 \pm 0.099^{\mathrm{aA}}$ & $9.350 \pm 0.042^{\mathrm{abA}}$ & $8.185 \pm 0.091^{\mathrm{abB}}$ & $7.645 \pm 0.148^{\mathrm{abC}}$ \\
\hline $\begin{array}{l}\text { Whey protein }+ \text { concentrate banana } \\
\text { stored at } 4^{\circ} \mathrm{C}\end{array}$ & $8.255 \pm 0.219^{\mathrm{aB}}$ & $9.51 \pm 0.127^{\mathrm{aA}}$ & $9.495 \pm 0.063^{\mathrm{aA}}$ & $8.455 \pm 0.081^{\mathrm{aB}}$ & $8.100 \pm 0.254^{\mathrm{aB}}$ \\
\hline $\begin{array}{l}\text { Whey protein + concentrate } \\
\text { strawberry stored at } 25^{\circ} \mathrm{C}\end{array}$ & $8.250 \pm 0.141^{\mathrm{aB}}$ & $9.180 \pm 0.113^{\mathrm{aA}}$ & $9.115 \pm 0.077^{\mathrm{cA}}$ & $7.975 \pm 0.071^{\text {bВ }}$ & $7.015 \pm 0.247^{\mathrm{bC}}$ \\
\hline $\begin{array}{l}\text { Whey protein }+ \text { concentrate } \\
\text { strawberry stored } 4{ }^{\circ} \mathrm{C}\end{array}$ & $8.245 \pm 0.205^{\mathrm{aB}}$ & $9.355 \pm 0.077^{\mathrm{aA}}$ & $9.215 \pm 0.049^{\mathrm{bcA}}$ & $8.205 \pm 0.077^{\mathrm{abB}}$ & $7.475 \pm 0.090^{\mathrm{aC}}$ \\
\hline
\end{tabular}

Different capital letters in each row showed significant $(P \leq 0.05)$ differences.

Different small letters in each column showed significant $(P \leq 0.05)$ differences.

The results are shown as mean \pm standard deviation.

\section{Changes of $\mathrm{pH}$ whey protein drink during fermentation and storage time}

Table 2 shows the changes of $\mathrm{pH}$ in whey protein drink during the storage period. The initial $\mathrm{pH}$ of the whey protein drink was 5.19. The $\mathrm{pH}$ decreased throughou 30 days' storage. After 30 days of storage the highest $\mathrm{pH}(\mathrm{pH}=3.81)$ was observed in the whey protein drink containing concentrate of banana and stored at $4{ }^{\circ} \mathrm{C}$ and the lowest $\mathrm{pH}$ (3.72) was observed in the whey protein drink containing concentrate of strawberry and stored at $25^{\circ} \mathrm{C}$.

The analysis of variance of $\mathrm{pH}$, in Table 5 . showed that the storage time, type of sample and their interactions had significant $(\mathrm{P} \leq 0.05)$ effect on the $\mathrm{pH}$ variation of whey protein drinks.

\section{GABA production in whey protein drink during storage time}

The results of GABA production in whey protein drink during fermentation and storage time are shown in Figure 1, and their chromatograms have been shown in Figure 2 and 3 . The amounts of GABA decreased during the storage time. The highest of GABA production $(252.5 \mathrm{ppm})$ was observed at whey protein drink containing banana concentrate stored at $25^{\circ} \mathrm{C}$ on the $15^{\text {th }}$ day and the lowest GABA content (131.5ppm) was observed in whey protein drink containing strawberry concentrate stored at $4{ }^{\circ} \mathrm{C}$. According to the results, drinks containing banana concentrate with similar storage conditions produced higher GABA levels than drinks containing strawberry concentrate.

Table 5 shows the analysis of variance of GABA production in whey protein drink containing concentrate of banana and strawberries stored at 4 and $25{ }^{\circ} \mathrm{C}$. 
According to the results of the effect of the storage time (days 15 and 30), effect of type of the sample (whey drinks containing strawberry and banana concentrates kept at 4 and $25^{\circ} \mathrm{C}$ ), and their interaction (sample type and storage time) on the amount of GABA changes was significant $(p \leq 0.05)$. According to the $\mathrm{F}$ factor, the effect of storage time on GABA changes in whey protein drink was significantly higher than other factors.

Table $2 \mathrm{pH}$ changes of whey protein drink containing banana or strawberry concentrate stored at $4{ }^{\circ} \mathrm{C}$ and $25^{\circ} \mathrm{C}$ for 30 days.

\begin{tabular}{|c|c|c|c|c|c|}
\hline Treatment & Before fermentation & $\begin{array}{c}\text { after } 72 \mathrm{~h} \\
\text { fermentation }\end{array}$ & $\begin{array}{l}2 \text { hours after } \\
\text { production }\end{array}$ & Days 15 & Days 30 \\
\hline $\begin{array}{l}\text { Whey protein }+ \text { concentrate banana } \\
\text { stored at } 25^{\circ} \mathrm{C}\end{array}$ & $5.19 \pm 0.000^{\mathrm{aA}}$ & $4.265 \pm 0.021^{\mathrm{aB}}$ & $4.23 \pm 0.001^{\mathrm{aB}}$ & $4.07 \pm 0.014^{\mathrm{abC}}$ & $3.77 \pm 0.028^{a D}$ \\
\hline $\begin{array}{l}\text { Whey protein+ concentrate banana } \\
\text { stored at } 4{ }^{\circ} \mathrm{C}\end{array}$ & $5.19 \pm 0.000^{\mathrm{aA}}$ & $4.295 \pm 0.007^{\mathrm{aB}}$ & $4.255 \pm 0.007^{\mathrm{aC}}$ & $4.105 \pm 0.006^{\mathrm{aD}}$ & $3.81 \pm 0.000^{\mathrm{aE}}$ \\
\hline $\begin{array}{l}\text { Whey protein + concentrate } \\
\text { strawberry stored at } 25^{\circ} \mathrm{C}\end{array}$ & $5.19 \pm 0.000^{\mathrm{aA}}$ & $4.250 \pm 0.014^{\mathrm{aB}}$ & $4.22 \pm 0.015^{\mathrm{aB}}$ & $4.04 \pm 0.014^{\mathrm{bC}}$ & $3.725 \pm 0.021^{\mathrm{aD}}$ \\
\hline $\begin{array}{l}\text { Whey protein }+ \text { concentrate } \\
\text { strawberry stored } 4^{\circ} \mathrm{C}\end{array}$ & $5.19 \pm 0.000^{\mathrm{aA}}$ & $4.285 \pm 0.007^{\mathrm{aB}}$ & $4.24 \pm 0.014^{\mathrm{aB}}$ & $4.10 \pm 0.013^{\mathrm{aC}}$ & $3.795 \pm 0.035^{\mathrm{aE}}$ \\
\hline
\end{tabular}

Different capital letters in each row showed significant $(P \leq 0.05)$ differences.

Different small letters in each column showed significant $(P \leq 0.05)$ differences.

The results are shown as mean \pm standard deviation.

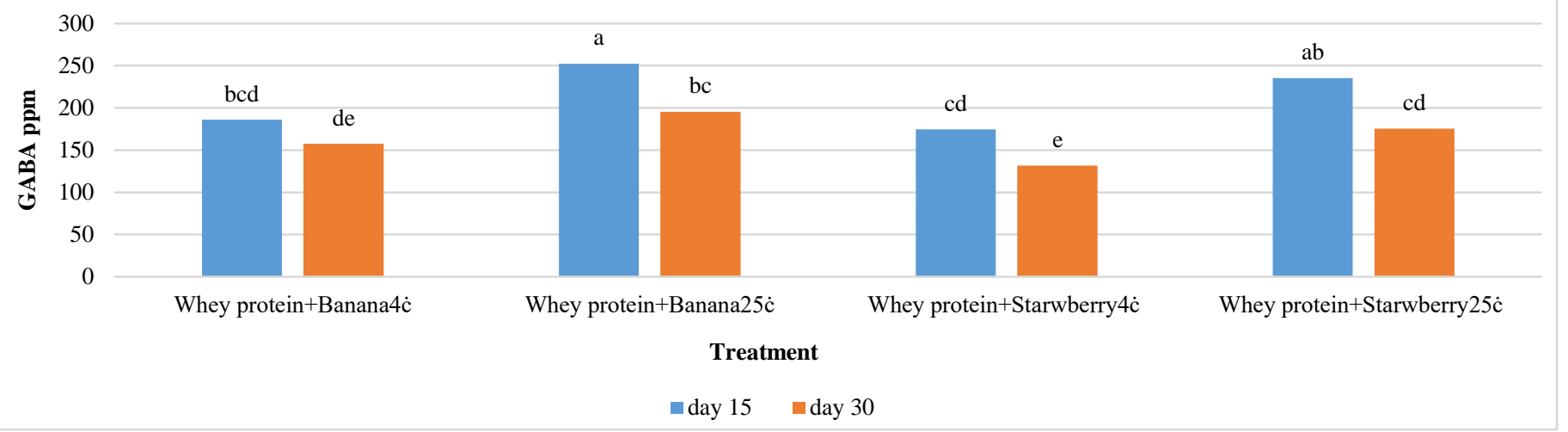

Figure 1 Results of GABA production in whey protein drink containing banana or strawberry concentrate stored at $4{ }^{\circ} \mathrm{C}$ and $25{ }^{\circ} \mathrm{C}$ on Day $15^{\text {th }}$ and Day $30^{\text {th }}$
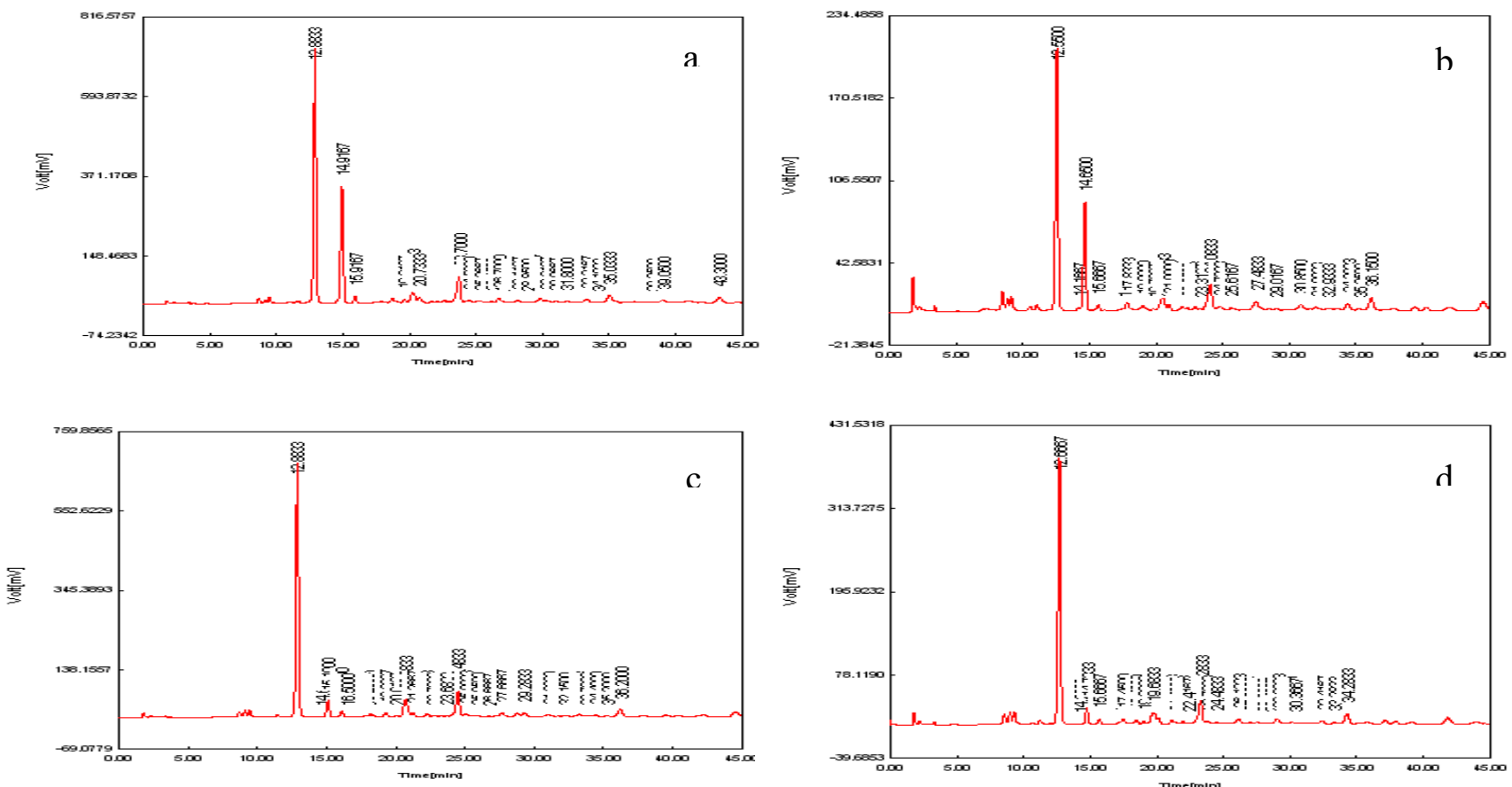

Figure 2 Chromatograms of the gamma-aminobutyric acid (GABA) production by lactic acid bacteria in drinks at day $15^{\text {th }}$ a) whey protein drink containing banana concentrate in $25{ }^{\circ} \mathrm{C}$ c) whey protein drink containing banana concentrate in $4{ }^{\circ} \mathrm{C}$, b) whey protein drink containing strawberry concentrate in $25{ }^{\circ} \mathrm{C}$ d) strawberry juice whey protein $4{ }^{\circ} \mathrm{C}$. 

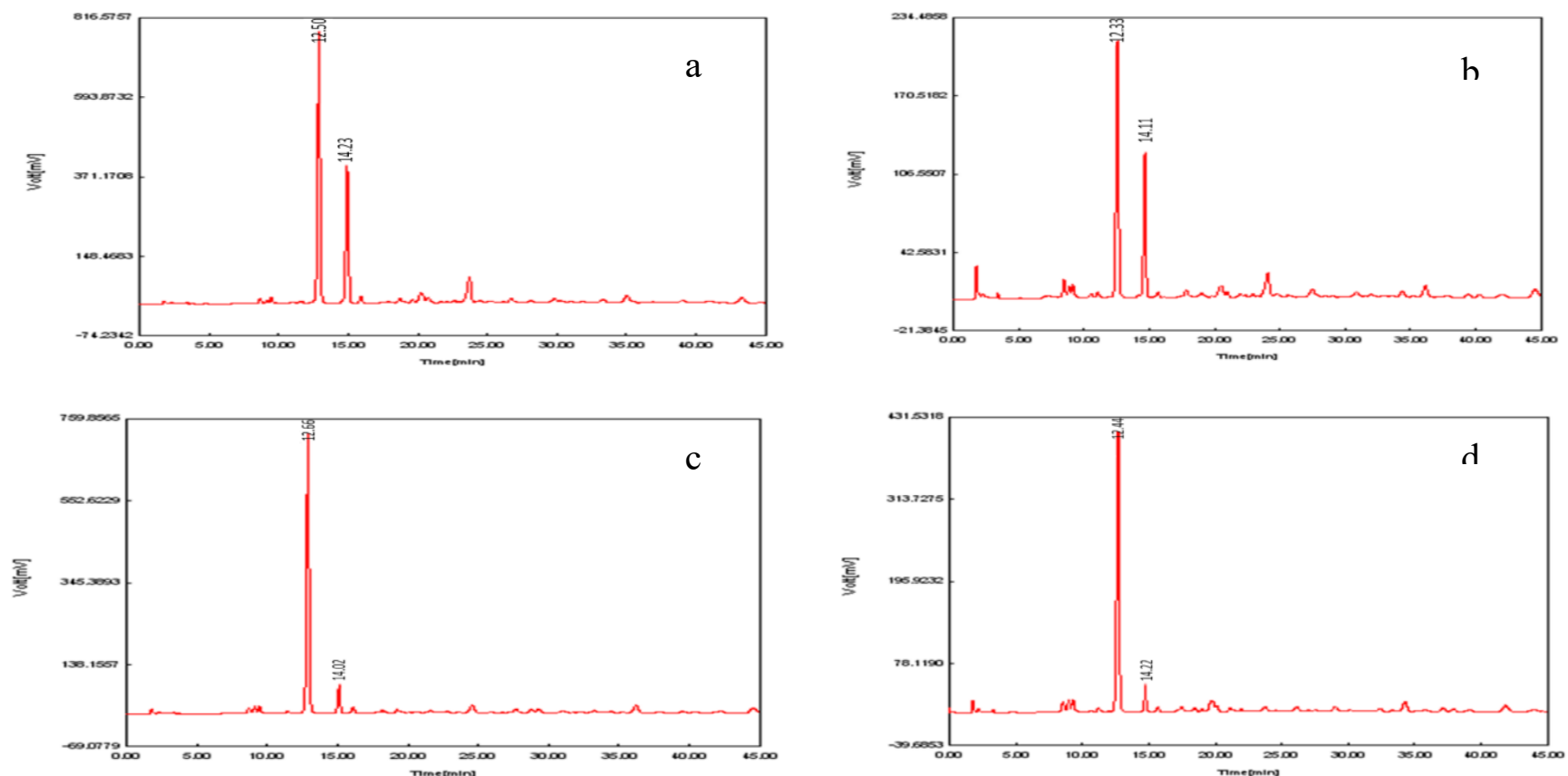

Figure 3 Chromatograms of the gamma-aminobutyric acid (GABA) production by lactic acid bacteria in drinks at day $30^{\text {th }}$ a) whey protein drink containing banana concentrate in $25^{\circ} \mathrm{C} \mathrm{c}$ ) whey protein drink containing banana concentrate in $4{ }^{\circ} \mathrm{C}, \mathrm{b}$ ) whey protein drink containing strawberry concentrate in $25^{\circ} \mathrm{C}$ d) strawberry juice whey protein $4^{\circ} \mathrm{C}$.

\section{Sensory evaluation}

\section{Changes of taste and smell of whey protein drink during storage time}

The mean taste and smell scores of the drink samples are presented in Table 3. The results showed that taste and smell of strawberry and banana inoculated with

Lb. plantarum decreased during the 30 days' storage, this decrease was not

significant $(\mathrm{p} \geq 0.05)$ in whey protein drinks containing banana concentrates and strawberries kept at $4{ }^{\circ} \mathrm{C}$, but significant $(\mathrm{p} \leq 0.05)$ for whey protein drinks containing banana concentrate and strawberries kept at $25^{\circ} \mathrm{C}$.

Table 5 shows the analysis variance of taste and smell of whey protein drinks. According to the results, storage time and type of the sample (whey drinks containing strawberry and banana concentrates kept at 4 and $25{ }^{\circ} \mathrm{C}$ ) had significant effect on taste and smell changes.

Table 3 Taste and smell results of whey protein drink containing banana or strawberry concentrate stored at $4{ }^{\circ} \mathrm{C}$ and $25{ }^{\circ} \mathrm{C}$ for 30 days

\begin{tabular}{|c|c|c|c|}
\hline Treatment & 2 hours after production & Days 15 & Days 30 \\
\hline $\begin{array}{l}\text { Whey protein }+ \text { concentrate banana } \\
\text { stored at } 25^{\circ} \mathrm{C}\end{array}$ & $5.00 \pm 0.000^{\mathrm{aA}}$ & $4.205 \pm 0.247^{\mathrm{aA}}$ & $4.495 \pm 0.247^{\mathrm{aA}}$ \\
\hline $\begin{array}{l}\text { Whey protein }+ \text { concentrate banana } \\
\text { stored at } 4^{\circ} \mathrm{C}\end{array}$ & $5.00 \pm 0.000^{\mathrm{aA}}$ & $4.075 \pm 0.247^{\mathrm{aB}}$ & $4.110 \pm 0.084^{\mathrm{aB}}$ \\
\hline $\begin{array}{l}\text { Whey protein }+ \text { concentrate } \\
\text { strawberry stored at } 25^{\circ} \mathrm{C}\end{array}$ & $5.00 \pm 0.000^{\mathrm{aA}}$ & $4.66 \pm 0.219^{\mathrm{aA}}$ & $4.675 \pm 0.233^{\mathrm{aA}}$ \\
\hline $\begin{array}{l}\text { Whey protein }+ \text { concentrate } \\
\text { strawberry stored } 4^{\circ} \mathrm{C}\end{array}$ & $5.00 \pm 0.000^{\mathrm{aA}}$ & $4.205 \pm 0.205^{\mathrm{aB}}$ & $4.180 \pm 0.084^{\mathrm{aB}}$ \\
\hline
\end{tabular}

Different capital letters in each row showed significant $(P \leq 0.05)$ differences.

Different small letters in each column showed significant $(P \leq 0.05)$ differences.

The results are shown as mean \pm standard deviation.

\section{Overall acceptability of whey protein drink during storage time}

The mean overall acceptability scores of the drink samples are presented in Table 4. There was a slight but not statistically significant $(p>0.05)$ reduction in overall acceptability rate of samples during 30 days' storage. The highest overall acceptance score (4.675) after 30 days of storage was belonged to whey protein drink sample containing strawberry concentrate kept at $25^{\circ} \mathrm{C}$, and the lowest total acceptance rating (4.115) was belonged to whey protein drink sample containing concentrate of banana stored in $4^{\circ} \mathrm{C}$ (Table 4).

Table 5 shows the analysis variance of overall acceptability of whey protein drinks. According to the results, storage time had significant $(p \leq 0.05)$ effect on overall acceptability of whey protein drink changes. The effect of type of the sample and the interaction effect of type of the sample and storage time on the overall acceptability of treatments was not significant ( $p>0.05$ ).
Table 4 Results of overall acceptability whey protein drink containing banana or strawberry concentrate stored at $4{ }^{\circ} \mathrm{C}$ and $25^{\circ} \mathrm{C}$ for 30 days.

\begin{tabular}{|c|c|c|c|}
\hline Treatment & $\begin{array}{c}2 \text { hours after } \\
\text { production }\end{array}$ & Days 15 & Days 30 \\
\hline $\begin{array}{l}\text { Whey protein+ } \\
\text { concentrate } \\
\text { banana stored at } \\
25^{\circ} \mathrm{C}\end{array}$ & $5.00 \pm 0.000^{\mathrm{aA}}$ & $4.577 \pm 0.247^{\mathrm{aA}}$ & $4.635 \pm 0.205^{\mathrm{aA}}$ \\
\hline $\begin{array}{l}\text { Whey protein }+ \\
\text { concentrate } \\
\text { banana stored at } \\
4^{\circ} \mathrm{C}\end{array}$ & $5.00 \pm 0.000^{\mathrm{aA}}$ & $4.100 \pm 0.353^{\mathrm{aA}}$ & $4.115 \pm 0.219^{\mathrm{aA}}$ \\
\hline $\begin{array}{l}\text { Whey protein }+ \\
\text { concentrate } \\
\text { strawberry stored } \\
\text { at } 25^{\circ} \mathrm{C}\end{array}$ & $5.00 \pm 0.000^{\mathrm{aA}}$ & $4.710 \pm 0.268^{\mathrm{aA}}$ & $4.675 \pm 0.247^{\mathrm{aA}}$ \\
\hline $\begin{array}{l}\text { Whey protein+ } \\
\text { concentrate } \\
\text { strawberry stored } \\
4^{\circ} \mathrm{C}\end{array}$ & $5.00 \pm 0.000^{\mathrm{aA}}$ & $4.300 \pm 0.226^{\mathrm{aA}}$ & $4.410 \pm 0.240^{\mathrm{aA}}$ \\
\hline
\end{tabular}


Table 5 Analysis variance of variables

Variables

Time of storage (A)

Type of sample (B)

Interaction $(\mathbf{A} \times \mathbf{B})$

\begin{tabular}{|c|c|c|c|c|c|c|}
\hline & & & & & \\
\hline & (P) & (F) & (P) & (F) & (P) & (F) \\
\hline viability L.plantarum & $0.000^{*}$ & 258.60 & $0.000^{*}$ & 19.53 & $0.015^{*}$ & 2.98 \\
\hline $\mathrm{pH}$ & $0.000 *$ & 10306.68 & $0.000 *$ & 18.89 & $0.000 *$ & 18.89 \\
\hline GABA & $0.000 *$ & 84.02 & $0.000 *$ & 38.86 & $0.018 *$ & 6.17 \\
\hline $\begin{array}{l}\text { Taste and smell } \\
\text { Overall acceptability }\end{array}$ & $\begin{array}{l}0.000 * \\
0.000 *\end{array}$ & $\begin{array}{l}38.25 \\
19.41\end{array}$ & $\begin{array}{c}0.007 * \\
0.208\end{array}$ & $\begin{array}{l}6.55 \\
2.29\end{array}$ & $\begin{array}{c}0.215 \\
1.12\end{array}$ & $\begin{array}{c}1.66 \\
0.408\end{array}$ \\
\hline
\end{tabular}

*Significant $\mathrm{P} \leq 0.05$

\section{DISCUSSION}

Changes viable counts of probiotic bacteria in whey protein drink during fermentation and storage time

The viability of $L b$. plantarum had ascending trend up to 72 hours in all whey protein drinks, which could be due to presences of nutritious elements within the whey protein and utilisation of available sugar by $L b$. plantarum. It is suggested that probiotics viability increase during fermentation period may be due to decrease in oxidation thus lower reduction potential as a result of diminishing levels of soluble oxygen in the medium (Saarela et al., 2006; Sadaghdar et al., 2012). Also research assessed the efficacy of whey proteins on the viability of probiotic bacteria during their maintenance period and reported that application of whey protein can significantly increase the viability of probiotic bacteria (Doherty et al., 2011). In this study, viability of $L b$. plantarum, 2 hours after production up to $30^{\text {th }}$ day of production, had descending trend in all samples suggesting sugar consumption by $L b$. plantarum, organic acids accumulation. This was supported by low $\mathrm{pH}$ values seen during the maintenance period, an effect was also reported previously (Donkor et al., 2006). Thus, showed that higher $\mathrm{pH}$ of probiotic bacteria medium and the initial equal population $\left(>10^{8}\right.$ $\mathrm{cfu} / \mathrm{ml}$ ), results in the reinforcement and increase in viability rates of $L b$. plantarum and Lb. connection (Sheehan et al., 2007). Addition of whey proteins can promote the buffer capacity and reduce the effect of the acidic environment on bacteria viability (Nadal $\boldsymbol{e t}$ al., 2010), thus improving overall acceptability. Other research reported viability of Saccharomyces boulardii in the fermented soybean drink reduced during storage period (Rekha and Vijayalakshmi, 2008), which was to low tolerability of Saccharomyces boulardii in an acidic environment. Similarly, reported that the utilization of probiotic mixture significantly enhances their viability due to the reinforcing and synergetic effects of probiotic bacteria (Wang et al., 2007).

\section{Changes $\mathrm{pH}$ of whey protein drink during fermentation and storage time}

In this study, the initial $\mathrm{pH}$ of all study samples prior to fermentation process were harmonized with no statistical difference between each sample. After 72 hours of fermentation, $\mathrm{pH}$ values of all samples significantly decreased compared to the baseline suggesting bacterial consumption of available sugars in the beverage leading to excess acid production within a given mixture. The highest $\mathrm{pH}(4.295)$ was seen in the whey protein drink containing banana concentrate, kept at $25^{\circ} \mathrm{C}$, and the lowest $\mathrm{pH}(4.25)$ was seen in the whey protein drink containing strawberry concentrate, kept at $4^{\circ} \mathrm{C}$. There were no statistical differences between the highest and the lowest $\mathrm{pH}$ changes indicating that the overall sugar bacterial consumption and acid production were similar at two storage conditions $\left(4^{\circ} \mathrm{C}\right.$ and $\left.25^{\circ} \mathrm{C}\right)$. There were $\mathrm{pH}$ reductions during the maintenance period (day 30). The highest $\mathrm{pH}$ value (3.81) was seen in whey protein drink containing banana concentrate, kept at $25{ }^{\circ} \mathrm{C}$, and the lowest $\mathrm{pH}$ value (3.72) was seen in whey protein drink containing strawberry concentrate, maintained at $4{ }^{\circ} \mathrm{C}$, with no significant differences between the samples. This finding suggest that homogeneity of sugar consumption and acid production by lactobacillus within the two medium (sugar content in mixtures containing strawberry and banana). Moreover, $\mathrm{pH}$ decrease during fermentation and maintenance periods could be due to decarboxylation of sorbic acid by Lb. plantarum, and its conversion into 1,3-pentadiene, as well as the production of carbon dioxide and ethanol (Cagetti et al., 2013).

\section{GABA production in whey protein drink during storage time}

There was a remarkable increase in GABA production in all samples up to day $15^{\text {th }}$ which started to progressively decline towards the day 30 . This decline could be, at least in part, due to degradation of alanine transaminase throughout the maintenance period (Le Vo et al., 2012). In order to the increase GABA production, decarboxylase conversion and inhibition of GABA aminotransferase are required (Wuand and Shah, 2018). Decrease in GABA level could be due to potential metabolism within citric acid cycle- conversion into succinic acid and oxalate (succinic dehydrogenase and malic acid dehydrogenase). This path causes that Krebs cycle to be decolorized and prevents $\mathrm{CO}_{2}$ production from $\mathrm{L}$ glutamine with subsequent reduction in GABA production (Le Vo et al., 2012).

A study reported optimal production of GABA from the fermented black raspberry drink by $\mathrm{Lb}$. Brevis bacteria occurred at $37^{\circ} \mathrm{C}$ with baseline $\mathrm{pH}$ of 5.5 (Kim et al., 2008). In this study, the maximum produced GABA content (195.5 $\mathrm{ppm})$ on $30^{\text {th }}$ day was seen with whey protein drink containing banana concentrate, kept at $25^{\circ} \mathrm{C}$ and statistically had significant difference $(\mathrm{p} \leq 0.05)$ with the whey protein drink containing strawberry and banana concentrates and kept at $4^{\circ} \mathrm{C}$. The minimum GABA production was in the whey protein drink treatment, containing strawberry concentrate, and kept at $4^{\circ} \mathrm{C}(131.5 \mathrm{ppm})$, which statistically had significant difference $(p \leq 0.05)$ with other treatments. The reason of GABA production difference in the whey protein beverage, containing banana and strawberry concentrates can be related to glutamic acid content percentage in banana (18.9\%) and strawberry (13.9\%) reported that the produced GABA by 112 milligrams per 100 milliliters in soy milk is instrumental and adequate for supplying pragmatic food. Thus research reported that the maximum produced GABA was in the samples of black raspberry drink that have been fermented at $37^{\circ} \mathrm{C}$ and observed on day 15 of production (Kim et al., 2008). They reported that the GABA content was higher than other treatments of the drinks that their initial pH was 4.5, 5, and 5.5 (Sheehan et al., 2007; Nadal et al., 2010).

\section{Changes of organoleptic properties of whey protein drink during storage} time

The bacterial population of lactic acid, present in probiotic products had significant effect on product scent. Acid lactic cultivation metabolism may result in the production of the compounds that have offensive sensory effects (smells) on final product aroma and possibly impacting the taste. Probiotic products could be acidic, have bitter and tangy tastes that may not be desirable to consumers (Wu, 2018). In this study, the highest score (4.675) of taste and smell after 30 days of maintenance period was seen for whey protein drinks containing strawberry concentrate and kept at $4^{\circ} \mathrm{C}$, and the lowest score (4.110) was reported for whey protein beverage containing banana concentrate and kept at $25^{\circ} \mathrm{C}$.

The negative score on scent and smell during maintenance period could be due to composite effects of probiotic bacteria activity, sugars consumption and organic acid production within the mixture (Fernández-Pascual et al., 2004). Moreover, increase in overall acid production leading to generation of disulphide gases could also contribute to the undesirable smell of the products at maintenance period (Granato et al., 2010).

The score of overall acceptability affected by the score of products taste and smell. The overall acceptability level was slightly decreased during the maintenance period (after 30 days storage time). Maximum score of overall acceptability after 30 days of storage period was 4.675 for whey protein drinks containing strawberry concentrate and kept at $4{ }^{\circ} \mathrm{C}$, whereas minimum score of overall acceptability (4.115) was reported for whey protein drinks containing banana concentrate kept at $25^{\circ} \mathrm{C}$. This decrease in overall acceptability score in the probiotic beverages during the maintenance period could be due to decreasing $\mathrm{pH}$ value, Brix content, probiotic bacteria death, increase in cell accumulation, increase in opacity, organic acid productions, and disulphide gases production, which in turn impact scent, taste, and overall smell score, acceptance score (Reddy et al., 2015).

In conclusion, using indigenous and resistant species of probiotic bacteria and optimizing bacterial growth conditions, more GABA can be produced in food products and a positive step towards the development of pragmatic products and the promotion of consumer health.

\section{CONCLUSION}

The acid lactic bacteria were grown in optimum conditions at $37.27{ }^{\circ} \mathrm{C}, \mathrm{pH} 5.19$, glutamic acid $250 \mathrm{mM}$ and time $72 \mathrm{~h}$ and then added to the whey protein drink containing banana and strawberry concentrate and viability, GABA production and sensory assessment was assessed for 30 days. The results showed that the highest viability $(9.51 \pm 0.127 \log \mathrm{cfu} / \mathrm{ml})$ was observed in the the whey protein drink containing concentrate of banana $72 \mathrm{~h}$ after fermentation and kept at $4{ }^{\circ} \mathrm{C}$. After 30 days of storage the highest $\mathrm{pH}(\mathrm{pH}=3.81)$ was observed in the whey protein drink containing concentrate of banana and stored at $4{ }^{\circ} \mathrm{C}$. The highest of GABA production $(252.5 \mathrm{ppm})$ was observed at whey protein drink containing 
banana concentrate stored at $25^{\circ} \mathrm{C}$ on the $15^{\text {th }}$ day and the lowest GABA content $(131.5 \mathrm{ppm})$ was observed in whey protein drink containing strawberry concentrate stored at $4{ }^{\circ} \mathrm{C}$. The results showed that taste and smell of strawberry and banana inoculated with $\mathrm{Lb}$. plantarum decreased during the 30 days' storage. This decrease was not significant $(\mathrm{p} \geq 0.05)$ in whey protein drinks containing banana concentrates and strawberries kept at $4{ }^{\circ} \mathrm{C}$. The highest total acceptance score (4.675) after 30 days of storage was belonged to whey protein drink sample containing strawberry concentrate kept at $25^{\circ} \mathrm{C}$.

The discovery of Lactobacillus extracted from traditional sources with the ability to synthesize GABA may provide new opportunities in the design of promoting reasonable foods with GABA-enriched benefits to consumer health. Such strains will accelerate the development of fermented foods.

Acknowledgements: The authors are grateful to Takgene Zist Company for carrying out the current study.

Ethics Approval (IRB/IACUC): The sensory evaluation was approved by the Institutional Review Board (IRB) at the Agricultural Research, Education and Extension Organization (AREEO), Tehran, Iran.

Conflict of interest: The authors declare no conflict of interest.

\section{REFERENCES}

Birollo, G.A. (2000). Viability of lactic acid microflora in different types of yoghurt. Food Research International Journal, 24: 399-805. https://doi.org/10.1016/S0963-9969(00)00101-0

Coda, R., Rizzello, C.G., Gobbetti, M. (2010). Use of sourdough fermentation and pseudo-cereals and leguminous flours for the making of a functional bread enriched of $\gamma$-aminobutyric acid (GABA). International Journal Food Microbial. 137: 236-245 https://doi.org/10.1016/j.ijfoodmicro.2009.07.016

Cagetti, M.G, Mastroberardino, S., Milia, E., Cocco, F., Lingström, P, Campus, G. (2013). The use of probiotic strains in caries prevention: A systematic review. Nutrients. 5:2530-50. https://doi.org/10.3390/nu5072530

Dhakal, R., Bajpai V. K.and Baek K.H. (2012). Production of GABA ( $\gamma$ aminobutyric acid) by microorganisms: a review. Brazilian Journal of Microbiology, 43 (4): 1230-1241. $\quad$ http://dx.doi.org/10.1590/S151783822012000400001.

Di Cagno, R.., Mazzacane, F., Rizzello, C.G., Angelis, M.D.E., Giuliani, G., Meloni, M., Servi, B.D.E., Marco, G. (2010), Synthesis of yaminobutyric acid (GABA) by Lactobacillus plantarum DSM19463: functional grape must beverage and dermatological applications. Applied Microbiology and Biotechnology, 86: 731-741. https://doi.org/10.1007/s00253-009-2370-4.

Doherty, S.B, Gee, V.L, Ross, R.P, Santon, C., Fitzgerald, G.F, Brodkorb, A (2011). Development and characterisation of whey protein micro-beads as potential matrices for probiotic protection. Food Hydrocolloid. 25:1604-1617. https://doi.org/10.1007/s10068-012-0019-z.

Donkor, O.N, Henriksson, A ., Vasiljevic, T. , Shah, N.P. (2006). Effect of acidification of probiotics in yoghurt during cold storage. International Dairy Journal. 16 (10): 1181-1189. https://doi.org/10.1016/j.idairyj.2005.10.008 Fernández-Pascual S., Mukala-Nsengu-Tshibangu A., Martín del Río, R. TamaritRodríguez J. (2004). Conversión into GABA (J-aminobutyric acid) may reduce the capacity of $\mathrm{L}$-glutamine as an insulin secretagogue. Biochemical Journal. 379: 721-729. https://doi.org/10.1042/bj20031826

Granato , D., Gabriel F.B, Nazzaro F, Cruz ,A, Faria , J. (2010). Functiona foods and nondairy probiotic food development: trends, concepts, and products Comprehensive Reviews in Food Science and Food Safety. 9(3):292 - 302 https://doi.org/10.1111/j.1541-4337.2010.00110.x.

Goyal, N., Gandhi, D.N. (2008). Whey, a carrier of probiotics against diarrhoea [Online].Available from: http://www. dairyscience.info/probiotics/110 wheyprobiotics. html?showall=1.

Harper, W.J. (2004). Biological Properties of Whey Components. A Review. Chicago, IL: The American Dairy Products Institute. 2001 with updates 2003

Kim, J.Y, Lee, M.Y., Ji, G.E., Lee, Y.S and Hwang, K, T. (2009). Production of $\gamma$-aminobutyric acid in black raspberry juice during fermentation by Lactobacillus brevis GABA100. International Journal of Food Microbiology, 130 (1): 12-16. https://doi.org/10.1016/j.ijfoodmicro.2008.12.028.

Larmond E. 1977. Laboratory Methods for Sensory Evaluation of Food. Research Branch, Department of Agriculture, Ottawa.

Leroy, F., Verluyten, J., and De Vuyst , L. ( 2006 ). Functional meat starter cultures for improved sausage fermentation. International Journal Food Microbiology, 106, 270 - 285. https://doi.org/10.1016/j.ijfoodmicro.2005.06.027 Leroy, F., Verluyten, J., and De Vuyst, L. (2006). Functional meat starter cultures for improved sausage fermentation. International Journal Food Microbiology, 106, 270 - 285. https://doi.org/10.1016/j.ijfoodmicro.2005.06.027.

Le VO, T. Kim, T.W, Hong, S.H. (2012). Effects of glutamate decarboxylase and gamma-aminobutyric acid (GABA) transporter on the bioconversion of GABA in engineered Escherichia coli. Bioprocess and Bio Systems Engineering .35:645650. https://doi.org/10.1007/s00449-011-0634-8.
Nadal, E.S.E., Sayae, Barberá J., Fernández-López J.A., Pérez-Alvarez, A. (2010). Food formulation to increase probiotic bacteria action or population. Bioactive Foods in Promoting Health: Probiotics and Prebiotics: 335-351. https://doi.org/10.1111/j.1750-3841.2008.00687.x

Nomura, M., Kimoto, H., Someya, Y., Furukawa, S., Suzuki, I. (1998) Production of gamma-aminobutyric acid by cheese starters during cheese ripening. Journal. Dairy

https://doi.org/10.3168/jds.S0022-0302 (98)75714-5.

Park, K.B., Oh, S.H. (2006). Isolation and characterization of Lactobacillus buchneri strains with high gamma-aminobutyric acid producing capacity from naturally aged cheese. Food Science Biotechnology, 15(1):86-90 https://doi.org/10.1007/s10068-014-0266-2.

Parvez, S., Malik, K., Ah Kang, S., Kim, H.Y. (2006). Probiotics and their fermented food products are beneficial for health. Journal Applied Microbiology, 100 (6):1171-85. https://doi.org/10.1111/j.1365-2672.2006.02963.x.

Okada, T., Sugishita, T., Murakami, T., Murai, H., Saikusa, T., Horino, T. Onoda, A., Kajimoto, O., Takahashi, R. and Takahashi, T. (2000). Effect of the defatted rice germ enriched with GABA for sleeplessness, depression, autonomic disorder by oral administration, Nippon Shokuhin Kagaku Kogaku Kaishi, Journal of the Japanese Society for Food Science and Technology, 47 (8) :596603.https://doi.org/10.3136/nskkk.47.596.

Saarela, M., Virkajarvi, I., Alakomi, H.L, SigvartMattila, P., Matto, J. (2006) Stability and functionality of freeze-dried probiotic Bifidobacterium cells during storage in juice and milk. International Dairy Journal. 16: 1477-1482. https://doi.org/10.1016/j.idairvj.2005.12.007

Sadaghdar, Y., Mortazavian, A.M., Ehsani, M. (2012). Survival and activity of five probiotic lactobacilli strains in two types of flavored fermented milk. Food Science Biotechnology. 1: 151-157. https://doi.org/10.1007/s10068-012-0019-z.

Sheehan, V.M., Ross, P., Fitzgerald, G.F. (2007). Assessing the acid tolerance and the technological robustness of probiotic cultures for fortification in fruit juices. Innovative Food Science \& Emerging Technologies. 8(2):279-284 http://dx.doi.org/10.1016/.ifset.2007.01.007.

Rekha, C.R, Vijayalakshmi, G. (2008). Biomolecules and nutritional quality of soymilk fermented with probiotic yeast and bacteria. Applied biochemistry and biotechnology.151 (2-3):452-63. http://dx.doi.org/10.1007/s12010-008-8213-4.

Reddy, L.B., Min, J.H., Wee, Y.W. (2015). Production of Probiotic Mango Juice by Fermentation of Lactic Acid Bacteria. Microbiology and Biotechnology letters. 43(2), 120-125. http://dx.doi.org/10.4014/mbl.1504.04007.

Wang, J.Z, Kondo, S., Yanagisawa, N., Miyaji, K., Enomoto, K., Sakoda, T. Iwatsuki, K. And Enomoto, T. (2007). Clinical efficacy of probiotic bifidobacterium longum for the treatment of symptoms of Japanese cedar pollen allergy in subjects evaluated in an environmental exposure unit. Allergology International. 56 (1): 67-75. https://doi.org/10.2332/allergolint.O-06-455.

Wu, Q., and Shah, N. P. (2018). Comparative mRNA-Seq analysis reveals the improved eps production machinery in Streptococcus thermophilus ASCC 1275 during optimized milk fermentation. Frontiers in Microbiology. 9:445. https://doi.org/10.3389/fmicb.2018.00445.

Yokoyama, S., Hiramatsu, J., Hayakawa, K. (2002). Production of gammaaminobutyric acid from alcohol distillery lees by Lactobacillus brevis IFO12005. Journal of Bioscience and Bioengineering, 93(1):95-7. https://doi.org/10.1263/jbb.104.34.

Zarei, F., Nateghi, L., Eshaghi, M., Taj abadi, M. (2018). Optimization of GammaAminobutyric Acid Production in Probiotics Extracted from Iranian Dairy Products using MRS and Whey Protein Media. Applied. Food. Biotechnology. 5 (4):233-242. https://doi.org/10.22037/afb.v5i4.23139. 